\title{
振動依存風力を考慮した風直角方向捩れ連成風応答解析方法に関する研究 ANALYTICAL METHODS FOR COUPLED WIND RESPONCE OF ACROSS-WIND AND TORSION WITH MOTION-INDUCED WIND FORCES
}

\author{
片 桐 純 治*, 大 熊 武 司**, 丸川 比佐夫*** \\ Junji KATAGIRI, Takeshi OHKUMA and Hisao MARUKAWA
}

\begin{abstract}
High-rise buildings are being increasingly constructed with vibration control devices or isolation devices. It is necessary to estimate the responses of these buildings in the high wind speed region where self-excited vibrations occur, such as self excited vortexinduced vibration, galloping and torsional flutter, in relation to their ultimate limit stage or damage control provided by their control devices.

This paper proposes a spectral analyzing method and a time history analyzing method using motion-induced wind force for wind responses of high-rise buildings with coupled across-wind and torsional vibrations, and discusses the validity of these methods. Results of spectral analysis considering coupled motion-induced wind forces show that the response to across-wind vibration increases at the wind speed at which the torsional response increases rapidly, when the natural frequency of across-wind vibration is lower than that of torsional vibration.
\end{abstract}

Keywords : $\quad$ Motion-induced wind force, Spectral Analysis, Time Series Analysis, Coupled Vibration 振動依存風力, スペクトル解析, 時刻歷解析, 連成振動

\section{1.はじめに}

最近の高層建築物では, 地震時の応答を抑えることを目的として 付加的減衰機構を設置した制振構造の高層建築物が建設されるよう になってきた.これまでの耐風設計ではマスダンパーあるいは粘性 ダンパーの場合の大変形時における有効性および信頼性あるいは弾 塑性ダンパーの強風時における継続時間に対する安全性の確認が不 十分なため, 応答振幅の小さい居住性の検討時のみ付加的減衰装置 の効果が考慮されてきた. しかし, 幅広い振幅に対応可能なダン パーの開発が行われており,加えて,免震装置を適用した高層建築 物も建設されつつある.これらの免震・制振装置を有する高層建築 物の高風速時における挙動を把握することは性能規定あるいは部分 損傷設計における安全性を確認するために必要である.

免震・制振装置を有する高層建築物では, 地震時の応答を抑える ことを目的として, 免震・制振装置を有さない高層建築物に比べ固 有振動数が低く目に設定されることが多い, そのため, 耐風設計時 において, 風外力による強制振動時の安全性ばかりでなく, 建築物 の振動と周辺流れの相互作用によって生じる振動依存風力作用時の 安全性の確認も必要となる.特に, 免震・制振装置の強風時の有効 性を確認するためには, 不安定振動の発振風速の予測だけでなく高 層建築物の渦励振, ギャロッピングおよび据れフラッター等の不安 定振動の風速範囲を含む応答予測, 寸なわち, 振動依存風力を考慮

\section{した風応答予測が必要になる.}

振動依存風力を考慮した風応答解析方法としては, 風直角方向振 動時の振動依存風力の速度比例成分より求まる空力減衰を取り入れ たスペクトル解析法による方法がVickery et al. ${ }^{1}$ により提案されて いる.この方法の妥当性は風直角方向振動あるいは据れ振動に関し て Steckley ${ }^{2}$, , 大熊他 ${ }^{3)}$ および片桐他 ${ }^{4)}$ 等による弾性模型実験結果 との比較により確認されている。一方, 著者等は多質点系弾性模型 を用いた風洞実験5),6)により，辺長比2あるいは3の偏心を有さな い高層建築物において振動依存風力による風直角方向と㨭れの連成 振動の生じることを指摘した. Vickery et al. ${ }^{1}{ }^{1}$ の方法ではこの振動 依存風力による連成振動時の応答予測は困難であり, 振動依存風力 による連成振動を考慮できる解析方法の確立が必要と考えられる. さらに,免震・制振装置を有する建築物では非線形な構造特性を有 するものが多い. 非線形な構造特性を有する高層建築物の風応答予 測には振動依存風力を考虑した時刻歷解析法が有用である.

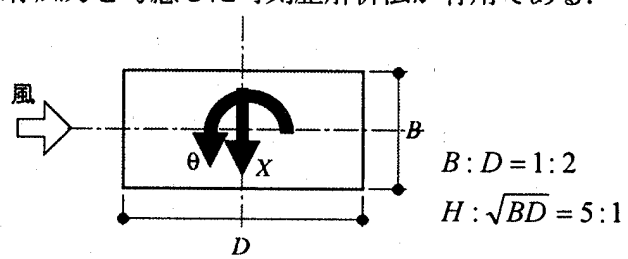

図1 対象建築物の平面形状および座標

\footnotetext{
本論文は文献11)を修正・加筆したものである。

*(俳)泉創建エンジニアリング都市環境技術研究所 主任研究員

** 神奈川大学建築学科 教授. 工博

*** (侏)泉創建エンジニアリング都市環境技術研究所 所長·工博
}

Chief Research Eng., Urban Environment Research Center, ISEC

Prof., Dept. of Arch., Faculty of Eng. Kanagawa Univ., Dr. Eng. Director, Urban Environment Research Center, ISEC, Dr. Eng. 
本研究は振動依存風力を考慮した高層建築物の風直角方向と㨭れ の連成風応答解析方法として,スペクトル解析による方法と時刻歷 解析による方法を提案し，それらの妥当性を検討するものである.

本研究では, 辺長比 $D / B=2(D$ : 奥行き, $B$ : 幅 $)$, アスペクト比 $H / \sqrt{B D}=5(H$ :高さ) の矩形平面を有する弾性挙動の高層建築物を 解析の対象とした.なお, 本研究で提案する時刻歴解析法は, 弾塑 性構造物の風応答解析にも適用可能なものである.

\section{2. 振動依存風力を考慮した風直角方向一㨝れ連成風応答解析 2.1スペクトル解析方法}

丸川他7による弾性模型実験によれば, 高層建築物に自励的振動 が生じる風速付近の応答は，一次振動成分の占める割合が二次以上 の高次振動成分に比べ十分大きく，応答予測において各方向の二次 成分は無視できる程度である. したがって, 本研究では, 風直角方 向および㧖れの一次振動を対象とする.なお, 本論文では, 振動依 存風力, 風外力, 質量, 剛性および減衰定数等は頂部質点のモード を1とする一次モードで一般化されたものとする.したがって，以 下の文章では「一般化」を省略し, 単に風力あるいは質量等と称す る.解析対象とする建築物の振動モードは直線モードとし; 重心お よび剛心位置は平面中心にあり，質量は一様に分布するものとする.

構造物の一次振動を対象とした場合, 周波数領域における振動依 存風力を考慮した振動方程式は(1)式で表される.

$$
\begin{gathered}
\left(2 \pi n_{X}\right)^{2} M_{X} H_{X}^{-1}(n) X(n)= \\
q_{H} D H\left\{C_{L W}(n)+C_{L X}(X, n)+C_{L \theta}(\theta, n)\right\} \\
H_{X}^{-1}(n)=1-\left(n / n_{X}\right)^{2}+i 2 h_{X} n / n_{X} \\
\left(2 \pi n_{\theta}\right)^{2} I_{\theta} H_{\theta}^{-1}(n) \theta(n)= \\
q_{H} D^{2} H\left\{C_{M W}(n)+C_{M X}(X, n)+C_{M \theta}(\theta, n)\right\} \\
H_{\theta}^{-1}(n)=1-\left(n / n_{\theta}\right)^{2}+i 2 h_{\theta} n / n_{\theta}
\end{gathered}
$$

ここで, $n_{X}, n_{\theta}$ : 固有振動数, $M_{X}, I_{\theta}$ :質量および慣性モーメント, $h_{X}$, $h_{\theta}$ : 構造滅衰定数, $q_{H}$ : 速度圧, $D, H$ : 奥行きおよび高さ, $C_{L W}(n)$, $C_{M W}(n)$ : 静止状態の建築物に作用寸る風直角方向風力係数および据 りモーメント係数, $C_{L X}(X, n), C_{M X}(X, n)$ : 風直角方向振動時の振動依 存風力係数で, それぞれ風直角方向変位に対する風直角方向振動依 存風力および振動依存㨝りモーメントを表す, $C_{L \theta}(\theta, n), C_{M \theta}(\theta, n)$ : 据れ振動時の振動依存風力係数で,それぞれ㨭れ変位に対寸る風直 角方向振動依存風力および振動依存㧖りモーメントを表す. $i=\sqrt{-1}$ である. 以後, 添え字の $X, \theta$ は模型の加振方向あるいは振動方向が それぞれ風直角方向および㨭れであることを表し，L,Mはそれぞれ 風直角方向風力および㨝りモーメントを表す.(1)式に(2)式の諸量 および(3)式を代入して整理すると,(4)式となる.
$A_{X}=\frac{3}{8 \pi^{2}} \frac{\rho_{a}}{\rho_{X}}\left(\frac{U_{H}}{n_{X} B}\right)^{2} \frac{B}{H}, \quad \rho_{X}=\frac{3 M_{X}}{B D H}, \quad \tilde{n}=\frac{n B}{U_{H}}$

$A_{\theta}=\frac{3}{8 \pi^{2}} \frac{\rho_{a}}{\rho_{\theta}}\left(\frac{U_{H}}{n_{\theta} B}\right)^{2}, \quad \rho_{\theta}=\frac{3 I_{\theta}}{B^{2} D^{2} H}, \quad \tilde{X}(n)=\frac{X(n)}{H}$

$\widetilde{H}_{X}^{-1}(n)=H_{X}^{-1}(n) / A_{X}, \quad \widetilde{H}_{\theta}^{-1}(n)=H_{\theta}^{-1}(n) / A_{\theta}$

$\widetilde{C}_{L X}(n)=C_{L X}(X, n) / \widetilde{X}(n) \quad \widetilde{C}_{M X}(n)=C_{M X}(X, n) / \widetilde{X}(n)$

$\widetilde{C}_{L \theta}(n)=C_{L \theta}(\theta, n) / \theta(n) \quad \widetilde{C}_{M \theta}(n)=C_{M \theta}(\theta, n) / \theta(n)$

$\widetilde{H}_{X}^{-1}(\widetilde{n}) \widetilde{X}(\widetilde{n})=C_{L W}(\widetilde{n})+\widetilde{X}(\widetilde{n}) \widetilde{C}_{L X}(\widetilde{n})+\theta(\widetilde{n}) \widetilde{C}_{L \theta}(\widetilde{n})$

$\widetilde{H}_{\theta}^{-1}(\widetilde{n}) \theta(\tilde{n})=C_{M W}(\widetilde{n})+\widetilde{X}(\widetilde{n}) C_{M X}(\widetilde{n})+\theta(n) \widetilde{C}_{M \theta}(\widetilde{n})$

ここで, $\rho_{a}$ : 空気密度, $B$ : 見付幅, $U_{H}$ :平均風速である. (3)式は, ランダム振動する変位波形が周波数の異なる調和振動の集合によっ て表され周波数毎に独立であり,かつ振動依存風力が変位に対する 線形関数と仮定して得られるものである.また, 各周波数毎の振動 依存風力は調和振動による強制加振実験より得られるものとする.

(4)式を, $\widetilde{X}(n)$ と $\theta(n)$ の二元連立方程式と見なし, (4)式を $\widetilde{X}(n)$ と $\theta(n)$ について解くと(5)式となる.

$$
\begin{aligned}
& \tilde{X}(\tilde{n})=\frac{C_{L W}(\widetilde{n})+\frac{C_{M W}(\widetilde{n}) \widetilde{C}_{L \theta}(\widetilde{n})}{\widetilde{H}_{\theta}^{-1}(\widetilde{n})-\widetilde{C}_{M \theta}(\widetilde{n})}}{\left\{\widetilde{H}_{X}^{-1}(\widetilde{n})-\widetilde{C}_{L X}(\widetilde{n})\right\}-\frac{\widetilde{C}_{M X}(\widetilde{n}) \widetilde{C}_{L \theta}(\widetilde{n})}{\widetilde{H}_{\theta}^{-1}(\widetilde{n})-\widetilde{C}_{M \theta}(\widetilde{n})}} \\
& \theta(\widetilde{n})=\frac{C_{M W}(\widetilde{n})+\frac{C_{L W}(\widetilde{n}) \widetilde{C}_{M X}(\widetilde{n})}{\widetilde{H}_{X}^{-1}(\widetilde{n})-\widetilde{C}_{L X}(\widetilde{n})}}{\left\{\widetilde{H}_{\theta}^{-1}(\widetilde{n})-\widetilde{C}_{M \theta}(\widetilde{n})\right\}-\frac{\widetilde{C}_{M X}(\widetilde{n}) \widetilde{C}_{L \theta}(\widetilde{n})}{\widetilde{H}_{X}^{-1}(\widetilde{n})-\widetilde{C}_{L X}(\widetilde{n})}}
\end{aligned}
$$

(5)式の分子第2項は振動依存風力の連成項により付加される風 力であり, 分母第2項は振動依存風力の連成項により生じる見かけ 上の剛性および減衰特性の変化を表している. (5)式より応答変位 のパワースペクトル密度は本頁下に示す (6) 式となる.ここで, $S_{C L W}(n), S_{C M W}(n)$ は風直角方向風力 $S_{C L W}(n)$ と㨝りモーメントの パワースペクトル密度 $S_{C M W}(n)$ をそれぞれ $\left(q_{H} D H\right)^{2}$ および $\left(q_{H} D^{2} H\right)^{2}$ で無次元化したものであり, $S_{C L M W}(n)$ は風直角方向風力 と据りモーメントのクロススペクトル密度を $q_{H}^{2} D^{3} H^{2}$ で無次元化し たものである. Re[・]㹥実数部を，*は共役を表す.

\section{2 時刻歷解析方法}

振動依存風力を考慮した振動方程式を時間領域について表すと (7)式となる.

$$
\begin{gathered}
M_{X} \ddot{X}(t)+4 \pi h_{X} n_{X} M_{X} \dot{X}(t)+4 \pi^{2} n_{X}^{2} M_{X} X(t)= \\
q_{H} D H\left\{C_{L W}(t)+C_{L a}(\varphi, \theta, t)\right\} \\
I_{\theta} \ddot{\theta}(t)+4 \pi h_{\theta} n_{\theta} I_{\theta} \dot{\theta}(t)+4 \pi^{2} n_{\theta}^{2} I_{\theta} \theta(t)=
\end{gathered}
$$$$
q_{H} D^{2} H\left\{C_{M W}(t)+C_{M a}(\varphi, \theta, t)\right\}
$$ 
ここで, $C_{L a}(\varphi, \theta, t), C_{M a}(\varphi, \theta, t)$ は風直角方向振動および㨭れ振動に よって生じる振動依存風力である.なお, 時刻歴解析の場合, 準定 常理論值を評価するため, 振動依存風力が迎角(風直角方向振動の 場合は振動速度と風速より求まる相対迎角 $\varphi$, 㧖れ振動の場合には 据れ角 $\theta$ ) を入力とするシステム関数であると仮定した. ただし， $\varphi(t)=\dot{X}(t) / U_{H}$ である.

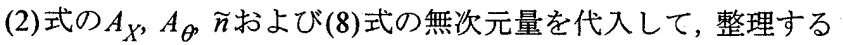
と(9)式となる.

$\widetilde{t}=\frac{t U_{H}}{B}, \tilde{X}(t)=\frac{X(t)}{H}, \lambda_{n}=\frac{n_{\theta}}{n_{X}}$

$\frac{\tilde{X}(\tilde{t})}{\left(2 \pi \tilde{n}_{X}\right)^{2}}+\frac{\tilde{X}(\tilde{t}) 2 h_{X}}{2 \pi \tilde{n}_{X}}+\tilde{X}(\tilde{t})=A_{X}\left\{C_{L W}(\tilde{t})+C_{L a}(\varphi, \theta, \tilde{t})\right\}$

$\frac{\ddot{\theta}(\tilde{t})}{\left(2 \pi \lambda_{n} \widetilde{n}_{X}\right)^{2}}+\frac{\dot{\theta}(\tilde{t}) 2 h_{\theta}}{2 \pi \lambda_{n} \widetilde{n}_{X}}+\theta(\tilde{t})=A_{\theta}\left\{C_{M W}(\tilde{t})+C_{M a}(\varphi, \theta, \tilde{t})\right\}$

振動依存風力 $C_{L a}(\varphi, \theta, t), C_{M a}(\varphi, \theta, t)$ は迎角之振動依存風力の応答関 数の畳み込み積分によって求められる.

$C_{L a}(\varphi, \theta, \tilde{t})=\int_{-\infty}^{\tau} \varphi(\tilde{t}-\tilde{\tau}) \tilde{C}_{L \varphi}(\widetilde{\tau}) d \tilde{\tau}+\int_{-\infty}^{\tau} \theta(\tilde{t}-\tilde{\tau}) \widetilde{C}_{L \theta}(\tilde{\tau}) d \tilde{\tau}$

$C_{M a}(\varphi, \theta, \tilde{t})=\int_{-\infty}^{\tilde{\tau}} \varphi(\tilde{t}-\tilde{\tau}) \widetilde{C}_{M \varphi}(\tilde{\tau}) d \tilde{\tau}+\int_{-\infty}^{\tau} \theta(\tilde{t}-\tilde{\tau}) \widetilde{C}_{M \theta}(\tilde{\tau}) d \tilde{\tau}$

$(10)$ 式中の $\widetilde{C}_{L \varphi}(\tilde{\tau}), \widetilde{C}_{M \varphi}(\widetilde{\tau}), \widetilde{C}_{L \theta}(\widetilde{\tau}), \widetilde{C}_{M \theta}(\tilde{\tau})$ は周波数領域 における振動依存風力を逆フーリ工変換して求められる.

$\widetilde{C}_{L \varphi}(\widetilde{\tau})=\int_{-\infty}^{\infty} \widetilde{C}_{L \varphi}(\widetilde{n}) e^{i 2 \pi \tilde{\tau} \tau} d \tilde{n}, \quad \widetilde{C}_{M \varphi}(\widetilde{\tau})=\int_{-\infty}^{\infty} \widetilde{C}_{M \varphi}(\widetilde{n}) e^{i 2 \pi \tilde{n} \tilde{\tau}} d \widetilde{n}(11 \mathrm{a})$ $\widetilde{C}_{L \theta}(\widetilde{\tau})=\int_{-\infty}^{\infty} \widetilde{C}_{L \theta}(\widetilde{n}) e^{i 2 \pi \tilde{n} \tilde{\tau}} d \widetilde{n}, \quad \widetilde{C}_{M \theta}(\widetilde{\tau})=\int_{-\infty}^{\infty} \widetilde{C}_{M \theta}(\widetilde{n}) e^{i 2 \pi \tilde{n} \widetilde{\tau}} d \tilde{n}(11 \mathrm{~b})$

ここで, $C_{L \varphi}(\tilde{n}), C_{M \varphi}(\tilde{n})$ は, 相対迎角に対する振動依存風力であり， 風直角方向変位に対する振動依存風力より(12)式で求められる.

$$
\begin{aligned}
& \widetilde{C}_{L \varphi}(\widetilde{n})=\widetilde{C}_{L X}(\tilde{n}) \frac{1}{i 2 \pi} \frac{U_{H}}{n_{0} B} \frac{B}{H} \\
& \widetilde{C}_{M \varphi}(\widetilde{n})=\widetilde{C}_{M X}(\widetilde{n}) \frac{1}{i 2 \pi} \frac{U_{H}}{n_{0} B} \frac{B}{H}
\end{aligned}
$$

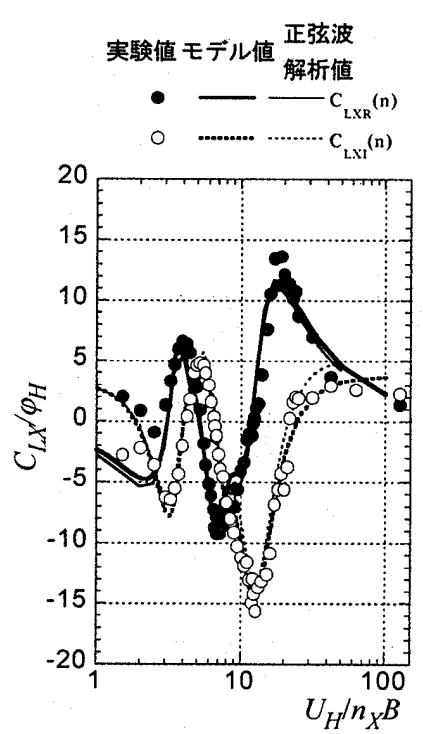

(i) 風直角方向振動時

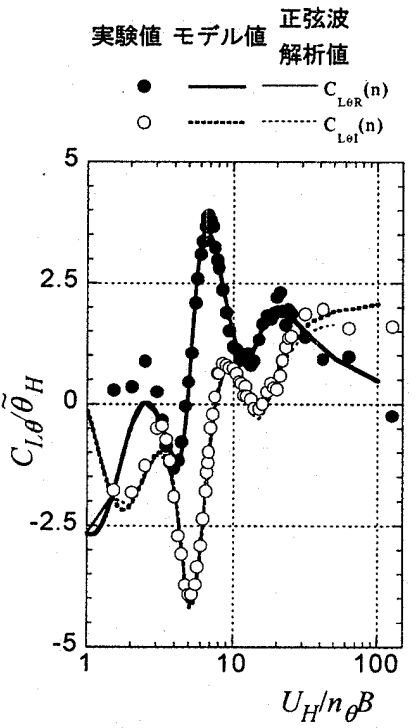

(ii) 读れ振動時 (a) 風直角方向振動依存一般化風力

図3 三次元模型に作用する非連成振動時振動依存一般化風力 (風直角方向振動時の風力は相対迎角で基準化したものを示す)

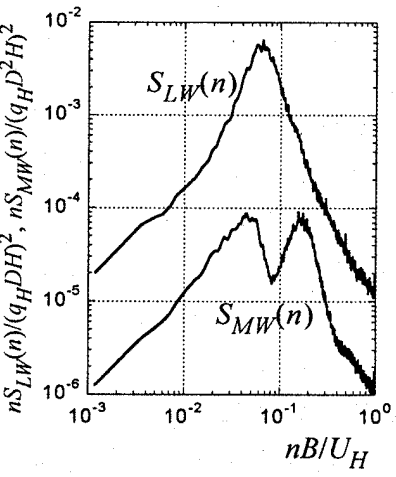

(a) パワースペクトル密度

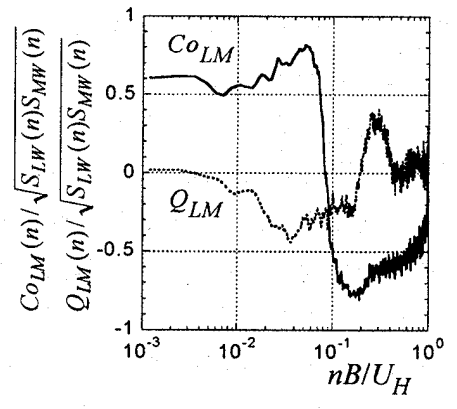

(b) クロススペクトル密度
図2一般化風カのパワースペクトル密度 およびクロススペクトル密度

なお, 実験より求まる振動依存風力を(11)式に適用するためには 関数近似によるモデル化が必要であり,3.2項において振動依存風力 のモデル化に関する検討を行う。

\section{3. 風外力特性および振動依存風力特性}

本項で用いた風力および振動依存風力は, $D / B=2, H / \sqrt{B D}=5$ の矩 形平面の実験模型を用いて,マニホールドにより測定した層風力に, 強制加振模型の鉛直方向の振動モード(直線モード)を掛けて求めた ものである4),8). 実験気流は, $\alpha=1 / 4$ の勾配流である.

\section{1 風外力特性}

図2に強制振動模型を静止させて測定した層風力より求めた風直 角方向風力および㧖りモーメントのパワースペクトル密度およびク ロススペクトル密度を示す. なお, 図20 $C_{L M}$ および $Q_{L M}$ はそれ ぞれクロススペクトル密度の実数部および虚数部を示す.

風直角方向風力は, 無次元周波数 0.06 付近をピークとするスペク トル形状である.据りモーメントは無次元周波数 0.04 と 0.15 付近に ピークを有している. 風直角方向風力と据りモーメントのクロスス ペクトル密度の実数部は, 㨭りモーメントのスペクトルギャップ付 近の周波数において正から負に符号が逆転する.虚数部は無次元周

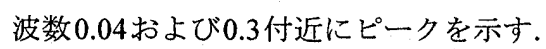

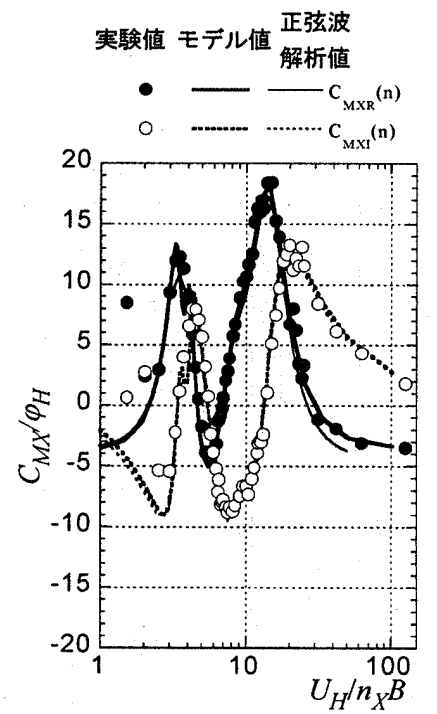

(i) 風直角方向振動時

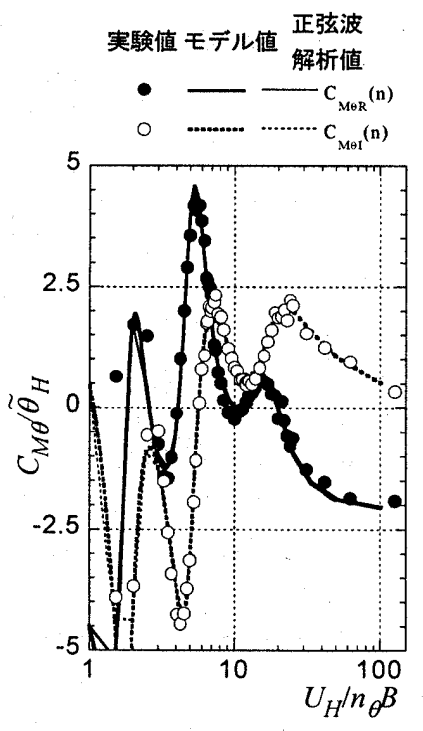

(ii) 据れ振動時 (b) 振動依存一般化据りモ一メント 


\section{2 振動依存風力特性}

\section{2.1 振動依存風力の測定結果}

図3に強制振動実験4)より求めた振動依存風力係数を示す.なお. 図3の $C_{L R}, C_{L I}$ はそれぞれ風直角方向振動依存風力係数の実数部(変 位比例成分)および虚数部(速度比例成分)を表し, $C_{M R}, C_{M I}$ はそれ ぞれ振動依存据りモーメント係数の実数部(変位比例成分)および虚 数部 (速度比例成分) を表す. 加振振幅は風直角方向振動時 $\widetilde{X}_{H}=X_{H}$ ' $H=0.005$, 据れ振動時 $\widetilde{\theta}_{H}=\theta_{H} D / 2 H=0.0025$ のものである. ここで, $X_{H}, \theta_{H}$ はそれぞれ頂部質点における風直角方向加振振幅および挨れ 加振振幅である. 図3の風直角方向振動時の振動依存風力係数は, 相 対迎角の振幅 $\varphi_{H X}=2 \pi n_{X} X_{H} / U_{H}$ で基準化したものである. 文献4),8) と基準化の方法が異なるが,これは後述する振動依存風力を相対迎 角の関数として近似するためである.なお, 図3中に示した実線お よび点線は後述する関数近似值およびこれを用いた調和振動時の解 析值である.

風直角方向振動時の風直角方向振動依存風力の速度比例成分は, $U_{H} / n_{X} B=5$ 付近の限定された風速および20付近以上において正值を 示し, 負減衰的に作用する. 㨭れ振動時の振動依存㨝りモーメント の速度比例成分は, $U_{H} / n_{\theta} B=6$ 付近以上において正值を示し, $U_{H} d$ $n_{\theta} B=7 お よ ひ ゙ 20$ 付近にピークを有する.振動依存据りモーメントの 速度比例成分がピークを示す風速は，据りモーメントのパワースペ クトル密度におけるピーク周波数と概ね一致している.

\section{2.2 振動依存風力の関数近似}

振動依存風力の絶対值は, 図4に示すように複数のピークを有し ている.これを考慮し，振動依存風力を(13)式に示す関数によって 近似した. なお，図40 $\beta_{L \varphi}$ および $\beta_{M \theta}$ はそれぞれ相対迎角および 据れ角に対する振動依存風力の位相差である.図2中に太い実線お よび点線で示した曲線が,(13)式によって関数近似した結果である. $\widetilde{C}_{L 0}=\bar{C}_{D}-\frac{\partial \bar{C}_{L}}{\partial \theta}, \quad \widetilde{C}_{M 0}=\frac{\partial \bar{C}_{M}}{\partial \theta}$

(13)式の右辺第一項の $\phi_{j}$ は, 迎角に対する振動依存風力の時間遅 れを表している. $m_{j}$ は0もしくは1として近似した. 表 1 に右辺第 一項の各パラメーターの近似值を示す.(13)式右辺第二項の $\widetilde{C}_{0}$ は,

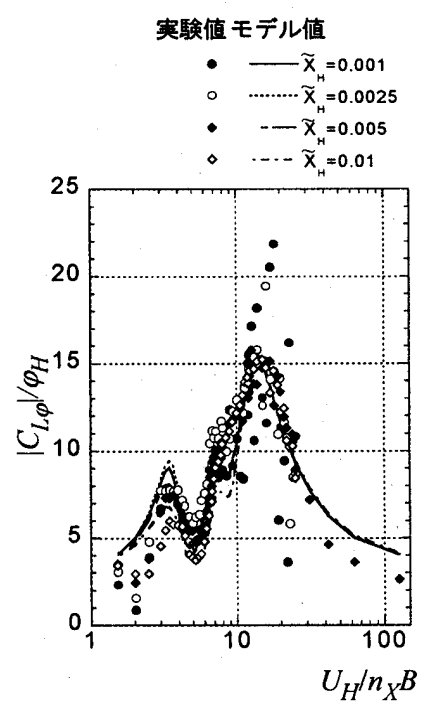

(i) 絶対値
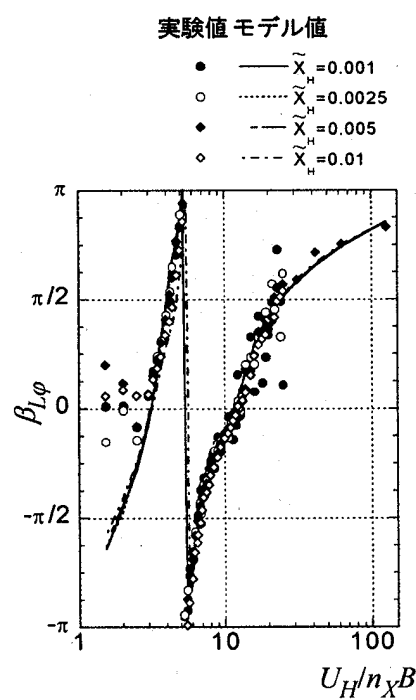

(i i) 位相差 （a）風直角方向振動依存一般化風力
(14)式から求まる準定常理論値である. 但し, $\widetilde{C}_{L 0}$ は風直角方向の 準定常理論値, $\widetilde{C}_{M 0}$ は㨭れの準定常理論值である.

$\widetilde{C}(\widetilde{n})=\sum_{j=1}^{3 o r 4} \frac{i a_{j}\left(\widetilde{n} / \tilde{n}_{j}\right)}{-\left(\widetilde{n} / \widetilde{n}_{j}\right)^{2}+i 2 h_{j}\left(\tilde{n} / \widetilde{n}_{j}\right)+1} e^{i\left(m_{j} \pi+\phi_{j} \tilde{n}\right)}+\widetilde{C}_{0}$

ここで, $\bar{C}_{D}, \bar{C}_{L}, \bar{C}_{M}$ はそれぞれ風方向平均風力係数, 風直角方向平均 風力係数および平均据りモーメント係数であり, 据れ加振用模型に 静的㨭れ角を与えて求めた. 本実験で得られた $\widetilde{C}_{L 0}$ および $\widetilde{C}_{M 0}$ はそ

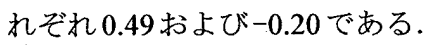

図5に応答関数の一例として $U_{H} / n_{X} B, U_{H} / n_{\theta} B=10$ の場合の振動依 存風力係数の関数近似モデルを逆フーリエ変換して求めた振動依存 風力の応答関数を示す.なお, 風直角方向振動時の応答関数は, 相 対迎角に対する応答関数を示している. 風直角方向振動依存風力の 場合, $\tilde{\tau}<0$ に若干応答値があり $\tilde{\tau}=0$ から始まる因果関数となって

表 1 近似パラメーター $\left(\widetilde{X}_{H}=0.005, \widetilde{\theta}_{H}=0.0025\right)$

\begin{tabular}{|c|c|c|c|c|c|}
\hline \multicolumn{2}{|c|}{$j$} & 1 & 2 & 3 & 4 \\
\hline \multirow{5}{*}{$C_{L X}$} & $a_{j}$ & -14.48 & -4.83 & -2.19 & -9.38 \\
\cline { 2 - 6 } & $n_{j}$ & 0.08 & 0.13 & 0.21 & 0.27 \\
\cline { 2 - 6 } & $h_{j}$ & 0.36 & 0.22 & 0.17 & 0.26 \\
\cline { 2 - 6 } & $\phi_{j}$ & -2.82 & 0.00 & 0.00 & -1.24 \\
\cline { 2 - 6 } & $m_{j}$ & 0 & 0 & 0 & 1 \\
\hline \multirow{5}{*}{$C_{M X}$} & $a_{j}$ & -1.60 & -3.24 & -2.56 & - \\
\cline { 2 - 6 } & $n_{j}$ & 0.07 & 0.18 & 0.53 & - \\
\cline { 2 - 6 } & $h_{j}$ & 0.37 & 0.26 & 0.36 & - \\
\cline { 2 - 6 } & $\phi_{j}$ & -2.08 & 1.50 & 0.00 & - \\
\cline { 2 - 6 } & $m_{j}$ & 0 & 0 & 0 & - \\
\hline \multirow{5}{*}{$C_{L \theta}$} & $a_{j}$ & 15.26 & 4.14 & 6.32 & 5.29 \\
\cline { 2 - 6 } & $n_{j}$ & 0.07 & 0.12 & 0.25 & 0.28 \\
\cline { 2 - 6 } & $h_{j}$ & 0.36 & 0.26 & 0.13 & 0.12 \\
\cline { 2 - 6 } & $\phi_{j}$ & -1.53 & -2.60 & 0.00 & -0.59 \\
\cline { 2 - 6 } & $m_{j}$ & 0 & 0 & 0 & 1 \\
\hline \multirow{5}{*}{$C_{M \theta}$} & $a_{j}$ & 1.87 & 3.29 & 2.96 & - \\
\cline { 2 - 6 } & $n_{j}$ & 0.06 & 0.20 & 0.54 & - \\
\cline { 2 - 6 } & $h_{j}$ & 0.40 & 0.26 & 0.22 & - \\
\cline { 2 - 6 } & $\phi_{j}$ & 0.00 & -2.77 & -1.91 & - \\
\cline { 2 - 6 } & $m_{j}$ & 0 & 0 & 0 & - \\
\hline
\end{tabular}

（太枠で囲んだパラメーターについては，振幅に対する 非線形性を考慮した関数近似も行った(図6).)
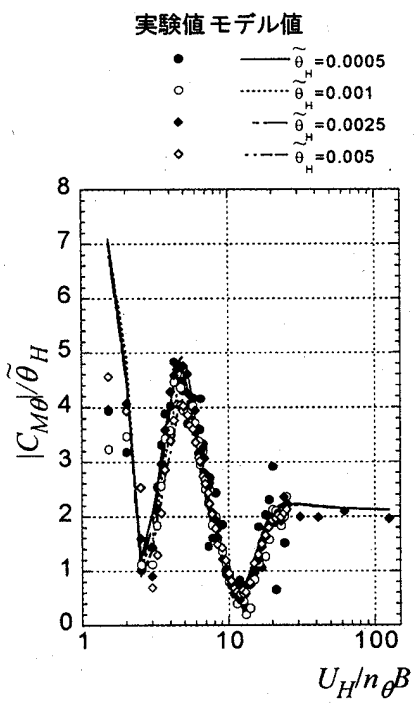

(i) 絶対値

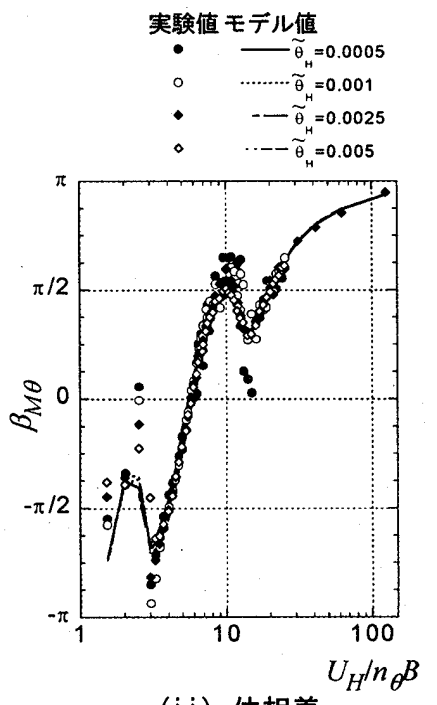

(ii) 位相差 （b）振動依存一般化㨝りモーメント 


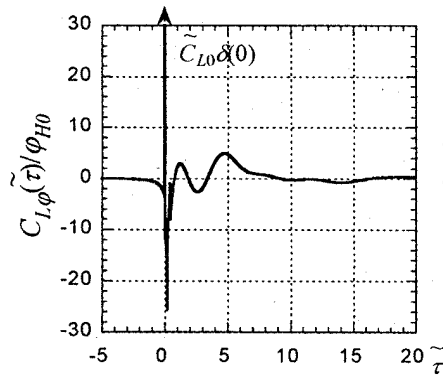

（a）風直角方向振動依存一般化風力
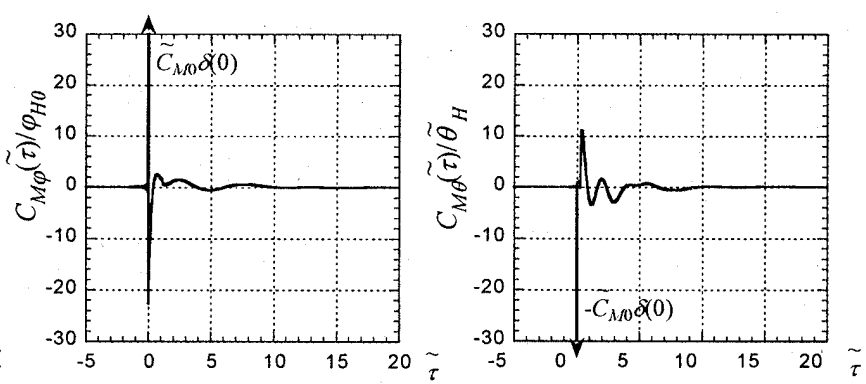

(b) 振動依存一般化㨭りモーメント

図5 振動依存風力の応答関数の一例 $\left(U_{H} / n_{0} B=10\right)$

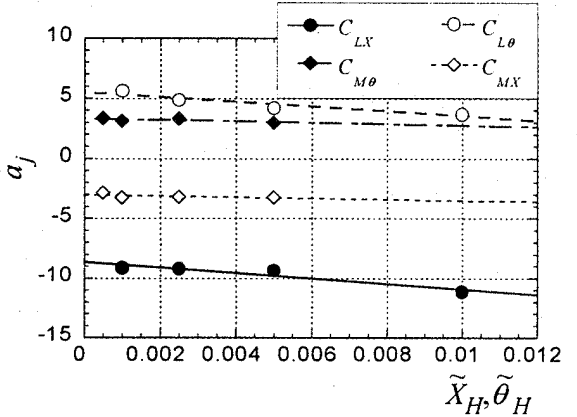

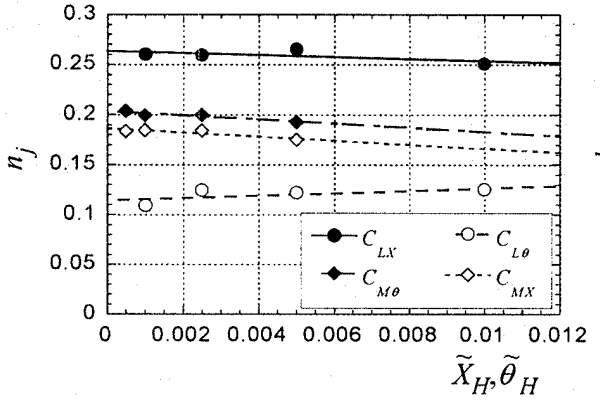

$\widetilde{X}_{H}, \widetilde{\theta}_{H}$

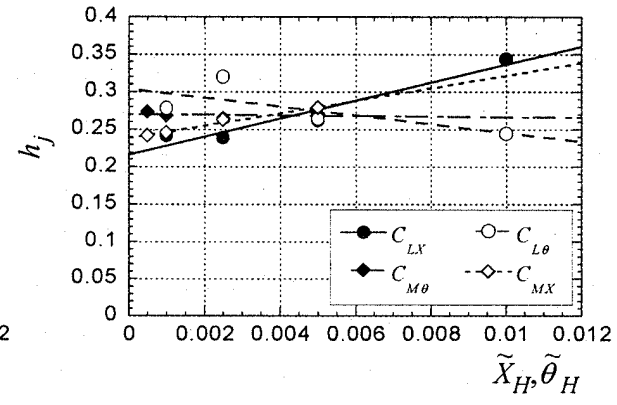

$\tilde{X}_{H}, \tilde{\theta}_{H}$
いない.これは, $U_{H} / n_{X} B, U_{H^{\prime}} n_{\theta} B=4$ 付近のピークを(13)式で近似 したとき, $m_{j}$ をとしたため逆フーリエ変換じて得られる関数が因 果関数とならないことによる.図 5 の $\tilde{\tau}>0$ における応答関数を用い て構造物が調和振動した時の振動依存風力を時刻歷解析より求めた 結果を前述の図3に細線で示したが, 風直角方向振動依存風力およ び振動依存据りモーメントとも関数近似したものとほぼ一致してお り, $\tilde{\tau}<0$ に応答值があることの影響は無視できる.

\section{2.3 振幅に対する非線形性を考慮した振動依存風力の近似}

強制加振実験より測定された振動依存風力の絶対值は, 図4に示 すように風直角方向振動依存風力および振動依存㨭りモーメントと も，無次元風速4～5付近を除き加振振幅に対して概ね比例する. 無 次元風速4 5付近では, 加振振幅が小さなほど振動依存風力の絶 対值は大きくなる傾向を示す. 振動依存風力が応答変位に対して比 例する場合, (5)式の分母第一項の実数部が 0 となる見かけ上の固有 振動数において虚数部が0以下となる場合がある。これは, 構造減 衰と空力減衰の和が0以下となり，振動が発散することを表してい る. 大熊他 ${ }^{8)}$ の二次元模型による低減衰時の振動実験によれば, 無 次元風速5付近では急激な応答変位の増加は見られるものの, 発散 的な振動は生じないのに対して, 無次元風速12付近では突然に発散 的振動が生じることが報告されている.これは, 図4における振動 依存風力の振幅依存性の傾向と一致する. そこで, 本研究では, 無 次元風速4 5付近をピークとする近似パラメーター(表1の太枠で 囲んだパラメーター)について振幅による非線形性を考慮した.な お,他のパラメーターについても同様に振幅依存性を考虑した近似 を行ったが, 表1の太枠で示したパラメーターについて振幅依存性 を考慮した場合が，実験值を最もよく近似した．また，図4におけ る振動依存風力の位相差は, 絶対值のような加振振幅による変化が 明瞭でないことより,位相差に関するパラメーターは振幅によって 変化しないものとした.

図4に振幅に対する非線形性を考慮した近似結果を, 図6に無次
元風速5付近の近似パラメーターの加振振幅による変化を示す.ほ とんどの近似パラメーターにおいて実験の加振振幅範囲内では, 単 調に増加あるいは減少する傾向が見られる. 本研究では, 図6に示 すように各近似パラメーターが加振振幅に対して一次関数的に変化 すると仮定して解析に用いた。

\section{4. 振動依存風力を考慮した風応答解析結果 4.1 スペクトル解析方法による風応答解析結果 \\ 4.1. 1 解析条件}

解析の対象とした構造物は, $\rho_{X} f \rho_{a}=163, \rho_{\theta} \rho_{a}=34, h_{X}=h_{\theta}=0.02$ と した。解析結果との比較に用いた弾性模型実験結果は, 文献5)にお ける $\propto=1 / 70$ 勾配流中で行われたものである.応答解析に用いた振 動依存風力は, 実験值を直線補間したものを用いた. 振動依存風力 の測定範囲外の周波数成分は変位比例成分および速度比例成分とも 0 とし, 振動依存風力は振幅と線形関係にあるとして, $X_{H} / H=0.005$ および $\theta_{H} D / 2 H=0.0025$ の結果を用いた.そのため, 据れ振動におい て構造減衰定数が $0.8 \%$ 以下の時, 無次元風速 8 付近において解析値 が発散し, 構造減衰定数が $0.8 \%$ より大きな場合は無次元風速 15 付 近において解析值が発散した.

スペクトル解析による風応答解析では, 履歷減衰などの非線形な 減衰特性を等価な線形減衰に置換する方法が取られており, 非線形 な減衰特性を考慮した詳細な検討は通常時刻歷解析により行われる. また, 一般的な高層建築物では $1 \sim 2 \%$ 程度の構造減数定数を有す ることおよび低減衰の建築物では制振装置等の設置されることが多 く, 通常の辺長比 20 高層建築物を対象とする風応答解析では, 振 動依存風力の振幅に対する非線形性を考慮していなことの実用上で の問題は生じることはまれであると考えられる.

\subsection{2 スペクトル解析による解析結果と弾性模型実験結果の比較}

図7にスペクトル解析による応答解析結果および弾性模型実験結 果5)の比較を示す. 図7は, 風直角方向と据れの固有振動数比 $n_{\theta} n_{X}$ 


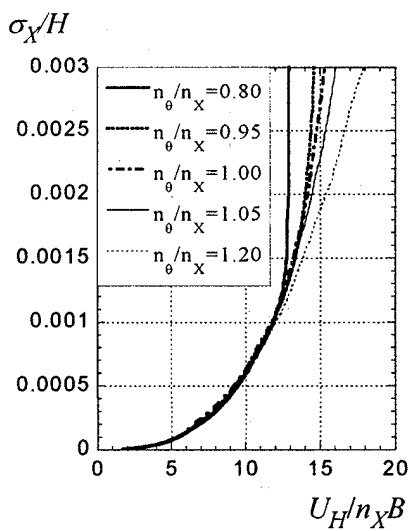

(i) 風直角方向

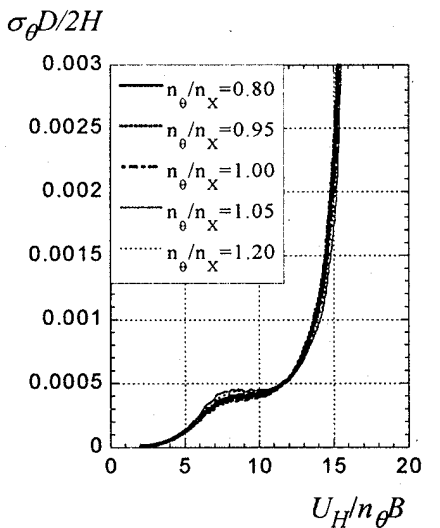

(ii) 㨝れ

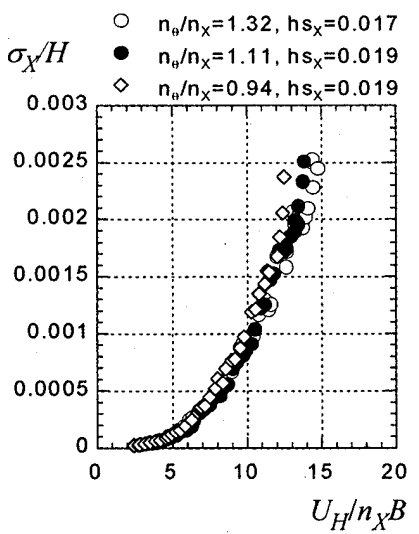

（i）風直角方向

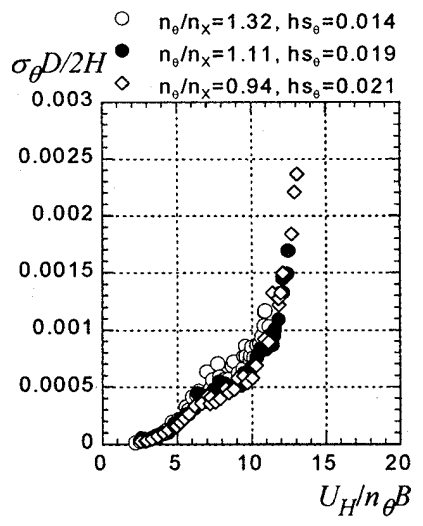

(ii) 㨝れ

(a) 解析值 $(h s=0.02)$

(b) 実験値 ${ }^{9)}$

図7 スペクトル解析による風応答解析結果と弾性模型実験結果の比較 （ $\rho_{X} / \rho_{a}=163, \rho_{\theta} \rho_{a}=34$, 振動依存風力は実験値を使用, 振動依存風力は振幅比例とした. )

の変化による応答性状の変化について求めたものである.

解析值に着目すると, 風直角方向変位は, $U_{H} / n_{X} B=12$ 以上の風速 において固有振動数比による増加の傾向が異り,振動依存風力の連 成項による差異が明瞭に現れている. 㧖れ変位には, 固有振動数比 による若干の差は見られるが, 風直角方向変位のような顕著な差は 生じていない.

実験值の場合, 固有振動数比による風直角方向変位の変化は, 無 次元風速13付近において解析值と同様の傾向を示している. 据れ変 位の実験值は $n_{\theta} n_{X}=1.32$ の場合他の固有振動数比の場合と比べ応答 変位が若干大きいが, これは他のケースと比べ減衰定数が小さい目 であることによると考えられる。

解析值と実験值を比較すると両者は実験気流が異なるものの風速 に対する応答変位の傾向は類似しており, 本研究で示した振動依存 風力を考虑したスペクトル解析による風直角方向㨭れ連成風応答解 析方法は妥当なものと考えられる.

\subsection{3 振動依存風力の連成項による風応答性状の変化}

図8に(6)式による応答解析值 $\sigma_{X}, \sigma_{\theta}$ と(6)式の連成項を除いた(15) 式より得られる応答解析值 $\sigma_{X I}, \sigma_{\theta I}$ の比を示す.
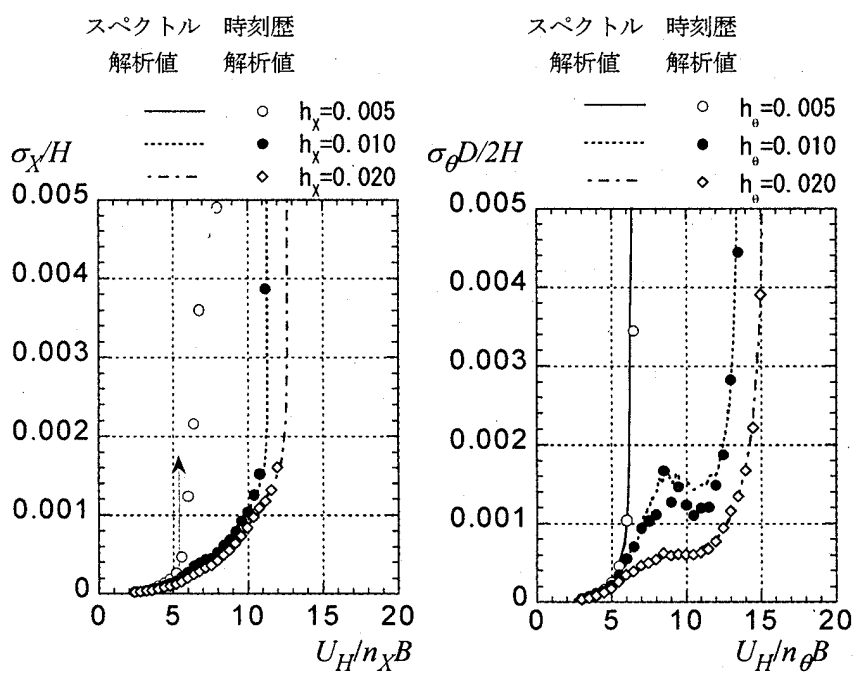

(a) $n_{\theta} / n_{X}=0.8$

$$
\begin{aligned}
& S_{\widetilde{X}}(\widetilde{n})=\frac{S_{C L W}(\widetilde{n})}{\left|\widetilde{H}_{X}^{-1}(\widetilde{n})-\widetilde{C}_{L X}(\widetilde{n})\right|^{2}} \\
& S_{\theta}(\widetilde{n})=\frac{S_{C M W}(\widetilde{n})}{\left|\widetilde{H}_{\theta}^{-1}(\widetilde{n})-\widetilde{C}_{M \theta}(\widetilde{n})\right|^{2}}
\end{aligned}
$$

なお, $U_{H} / n_{X} B$ および $U_{H} / n_{\theta} B$ が 15 を超えた風速で結果が途切れて

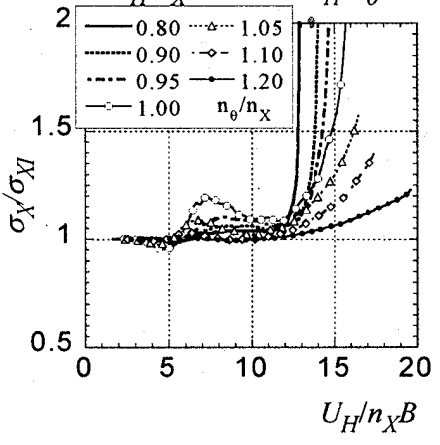

(a) 風直角方向変位

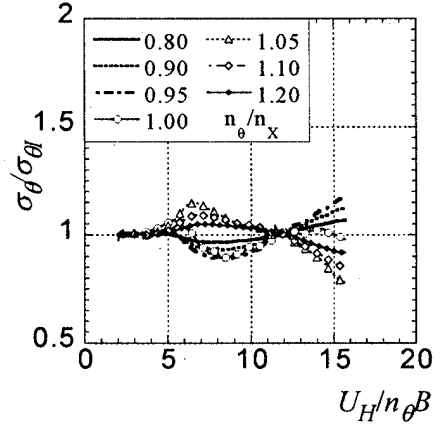

(b) 㨝れ変位 図8 振動依存風力の連成項による応答変位の変化 $\left(\rho_{X} / \rho_{a}=163\right.$, $\rho_{\theta} \rho_{a}=34, h_{X}=h_{\theta}=0.02$, スペクトル解析, 振動依存風力は実験値)
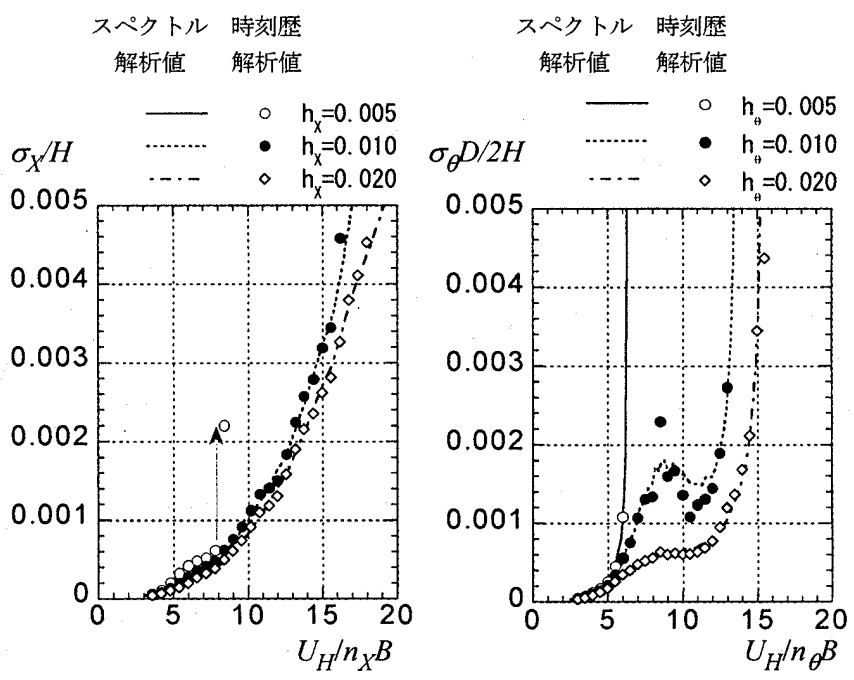

(b) $n_{\theta} n_{X}=1.2$

図9 スペクトル解析値と時刻歴解析値の比較 $\left(n_{\theta} / n_{X}=1.1, \rho_{X} / \rho_{a}=163, \rho_{\theta} d \rho_{a}=34\right.$,

スペクトル解析時の振動依存風力は関数近似値, 振動依存風力は振幅比例とした） 
いるものがあるが,これは据れの解析值が発散したため計算を打ち 切ったことによる.

風直角方向変位の場合, $U_{H} / n_{X} B=12$ 付近から $\sigma_{X} / \sigma_{X I}$ の増加が見 られる.この傾向は, 固有振動数比が小さなほど顕著である. $n_{\theta}\left(n_{X}\right.$ $=0.95$ 以下の $\sigma_{X} / \sigma_{X I}$ が増加する風速は，据れ変位が急激に増加する 風速と概ね一致する. また, $U_{H} / n_{X} B=7$ 付近では高風速ほど顕著で はないが, $n_{\theta} n_{X}=1.0$ の時 $\sigma_{X}$ が $\sigma_{X I}$ より2割程度增加する. 㨭れ変位 の場合, 風直角方向変位ほど顕著な差異は見られないが, $U_{H} / n_{\theta} B=5$ $\sim 12$ の範囲では $n_{\theta} / n_{X} \geqq 1.05$ の時 $\sigma_{\theta}$ が $\sigma_{\theta I}$ に比べ大きく, $U_{H} / n_{\theta} B=12$ 以上では $n_{\theta} n_{X} \leqq 1.00$ 時 $\sigma_{\theta}$ が $\sigma_{\theta l}$ に比べて大きい.

\section{2 時刻歴解析方法による風応答解析結果}

まず, 本研究で提案する時刻歷解析結果の妥当性を, 時刻歷解析 およびスペクトル解析による風応答解析を同様の解析条件により行 い, 両者の比較より検討する. その際, スペクトル解析と同様に時 刻歷解析においても振動依存風力は加振振幅に比例するものとして 解析を行った. 続いて, 振動依存風力の非線形性を考慮した応答解 析を行い, 弾性模型実験結果との比較を行う。

\subsection{1 時刻歴解析とスペクトル解析による風応答解析結果の比較}

解析対象とした建物モデルは密度比 $\rho_{X} / \rho_{a}=163, \rho_{\theta} \rho_{a}=34$, 風直角 方向と据れの固有振動数比 $n_{\theta} / n_{X}=0.8,1.2$, 減衰定数 $h_{X}, h_{\theta}=0.5 \%, 1 \%$ および $2 \%$ とした. 時刻歴解析結果との比較のためスペクトル解析 においても関数近似した振動依存風力を用いた。時刻歷解析時の風 力の時系列は, 図3のパワースペクトル密度およびクロススペクト ル密度を基にモンテカルロ法で作成した. 時刻歴解析は線形加速度 法により行い解析時の時間刻みは据れ固有周期 $T_{\theta}$ の1/100, 解析時 間は $T_{\theta}$ の 300 倍の解析を 5 波行い, $100 T_{\theta}$ から $300 T_{\theta}$ の解析結果 5 波の標準偏差のアンサンブル平均值を求めた. 解析では1ステップ 毎の無次元変位の変化量が $10^{-10}$ 以下となるまで収束計算した.

図9に時刻歷解析およびスペクトル解析による風応答解析結果の 比較を示す.なお，振動依存風力の実験值を用いた図6のスペクト ル解析結果と近似值を用いた図8のスペクトル解析結果が同様な結 果が得られていることより,関数近似誤差による応答解析結果への 影響はほとんど無いものと考えられる.

\section{スペクトル解析と時刻歷解析による結果を比較すると, 固有振動}
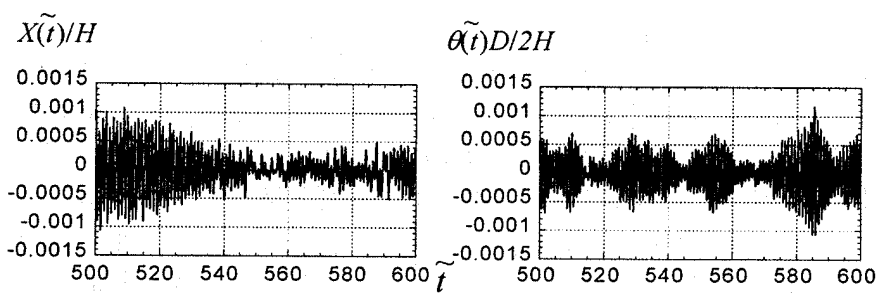

(i) $U_{H} / n \theta^{B=5}$

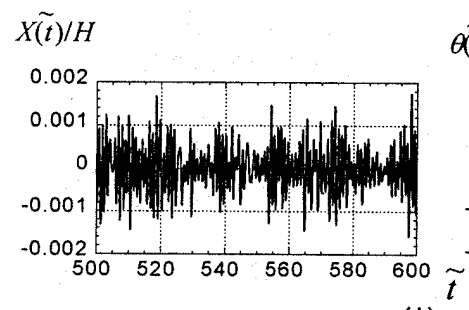

$\tilde{\theta(t)} D / 2 H$

(a) $h_{X}=0.005, h_{\theta}=0.005$

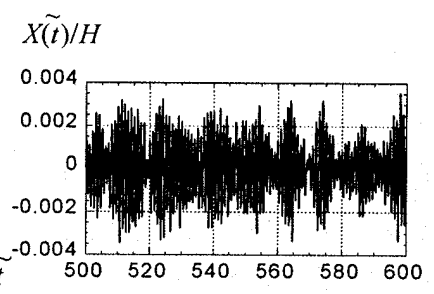

図10 振幅に対する非線形性を考慮した風応答解析結果と 弾性模型実験結果 ${ }^{10)}$ の比較 $\left(n d n_{X}=1.1, \rho_{X} / \rho_{a}=163, \rho_{d} d \rho_{a}=34\right)$

$\tilde{\theta(t) D / 2 H}$

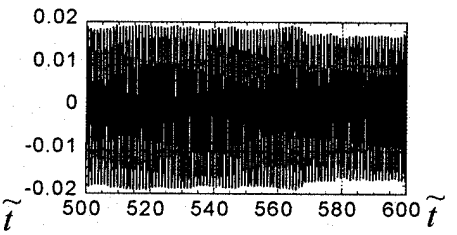

(ii) $U_{H} / n_{\theta} B=8$
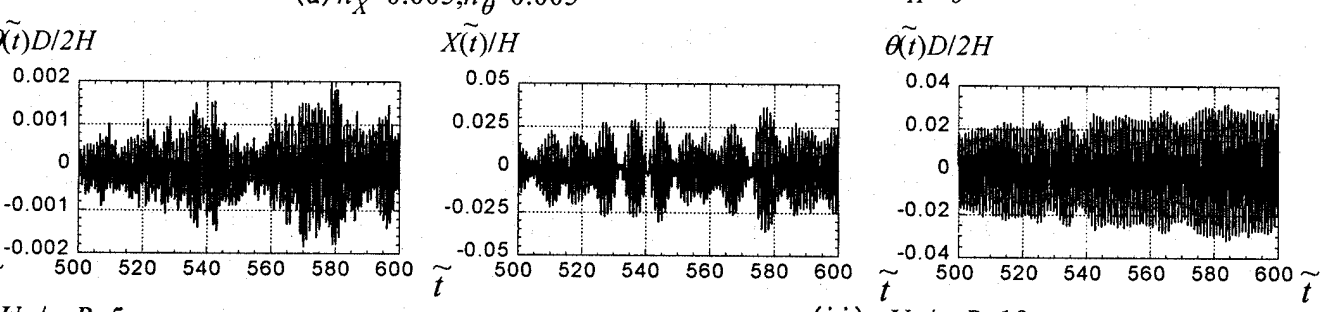

(i i) $U_{H} / n_{\theta} B=18$

振動依存風力の非線形性を考慮した時刻歷解析では, 非線形性を 考慮しない場合に比べ,解析結果が定常になるまでの解析時間がか かるため, 解析時間は $T_{\theta}$ の600倍とし, 300T $T_{\theta}$ から600T $T_{\theta}$ における

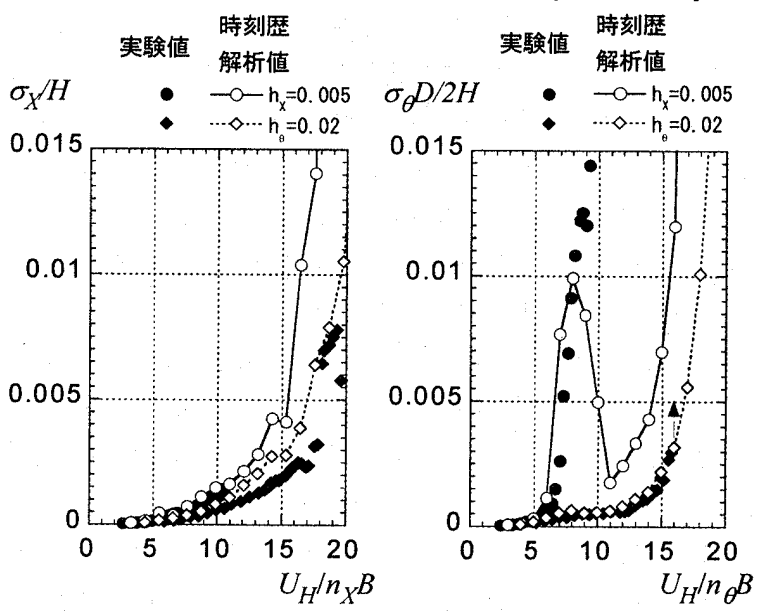

(i) $U_{H} / n_{\theta}^{B=5}$

(b) $h_{X}=0.02, h_{\theta}=0.02$

図11 時刻歴解析における応答波形 $\left(n_{\theta} / n_{X}=1.1, \rho_{X} \nmid \rho_{a}=163, \rho_{\theta} \rho_{a}=34\right)$ 
標準偏差を求めた.その他の時刻歷解析方法および風外力時系列の 作成方法は, 4.2.1項と同じである。

時刻歴解析時の構造物の風直角方向亡据孔の固有振動数比, 密度 比は比較を行う弾性模型実験 ${ }^{10)}$ に合わせて $\rho_{X} / \rho_{a}=163, \rho_{\theta} \rho_{a}=34, n_{\theta}$ $n_{X}=1.1$ とした. 構造減衰定数は $0.5 \%$ おび $2 \%$ とした.

図10に振動依存風力の非線形性を考虑した風応答解析結果と弾性 模型実験結果の比較を示す.図10に示した構造減衰定数約 $2 \%$ 弾 性模型実験結果は勝村他 ${ }^{10}$ にに示されているものであり,べき指数 $\alpha=1 / 4$ の実験気流中で行われたものである.構造減衰定数約 $0.5 \%$ の 結果は文献10)と同じ実験条件により行ったものである.

弾性模型実験結果によると, 減衰定数 $0.5 \%$ 時, $U_{H} / n \theta^{B=5}$ 付近 から据れ振動に忘答変位の急激な増加が見られるものの, 発散は生 じていない, 減衰定数 $2 \%$ の時, 文献 10$)$ によると, $U_{H} / n_{\theta}^{B=15}$ 付 近において応答変位に発散的な増加が生じており, 据れ変位 $\sigma_{\theta} D / 2 H$ に0.1程度の変形が生じた時, 弾性模型の柱が塑性化し, $U_{H} / n \theta^{B=19}$ 付近において破断した。

時刻歷解析結果の場合, 減衰定数 $0.5 \%$ の時, 応答変位は $U_{H} / n_{\theta} B=8$ 付近において極大值を示し, 風速の増加に伴って応答变位が減少し た後, $U_{H} / n_{\theta} B=15$ 付近において急激な応答変位の増加が生じてい る. 減衰定数 $2 \%$ の時, 低風速での限定振動は起こらず, $U_{H} / n \theta^{B=18}$ を超える風速で急激な応答変位の増加が生じている.

弾性模型実験結果と時刻歷解析結果を比較すると, 減衰定数 $0.5 \%$ および $2 \%$ の場合とも定性的傾向は概ね一致しており, 本研究にお ける振動依存風力のモデル化の有效性が示されたものと考えられる.

図 11 に時刻歷解析による応答变位波形の一例を示す. 減衰定数 $0.5 \%$ および $2 \% の U_{H} / n \theta=5$ における変位波形は, 風直角方向変位 および据れ変位ともランダムな応答波形である. 一方, 減衰定数 $0.5 \% の U_{H} / n \theta^{B=8}$ および減衰定数 $2 \% の U_{H} / n \theta^{B=18}$ では, 風直角方 向変位はビートした応答波形であり, 据れ変位は比較的振幅変化の 少ない正弦波的な波形を示している. 著者等は文献5)の弾性模型実 験において, 据れ変位に急激な増加が生じた場合, 風直角方向の応 答変位には, 風直角方向の固有振動数成分と㧖れの固有振動数成分 の割合がほぼ等しくなる現象が生じるを示しておう, 本研究の時刻 歴解析においても同様の現象が生じるため風直角方向変位がビート した振動になるものと考えられる.

\section{5. 結論}

振動依存風力を考慮した高層建築物の風直角方向と据れの連成応 答を対象としたスペクトル解析法および時刻歷解析法を示し, それ らの妥当性について検討した.また, スペクトル解析法により振動 依存風力の連成項による風直角方向および㨭れ振動における風応答 の変化に関して検討した. 本研究の結論を以下に示す.

1) スペクトル解析による応答解析結果と弾性模型実験結果の固有 振動数比による变化の傾向は概ね一致しており, 本研究で提案し たスペクトル解析による応答解析方法は妥当なものと考えられる. ただし,スペクトル解析方法では, 振動依存風力を振幅に比例す るとしているため, 減衰定数が $0.8 \%$ より小さい場合には無次元風 速 8 付近において, 減衰定数が $0.8 \%$ より大な場合無次元風速 15 付近において解析值が発散した。

2) 本研究で提案した時刻歴解析法による解析結果はスペクトル解
析法によるものと一致した結果が得られたことより,本研究で提 案した時刻歷解析方法は妥当なものと考えられる.また, 振動依 存風力の振幅に対する非線形性を考慮した時刻歷解析結果は, 弾 性模型実験結果とほぼ一致した傾向が得られた.

3) 本研究で提案した振動依存風力を考慮した風応答解析方法の適 用例として, 風直角方向と㧖れの固有振動数比による振動性状の 変化に関して検討した. 振動依存風力の連成項を考慮しない場合 と比較し, 振動依存風力の連成項を考慮した場合, 辺長比 20 建 築物では㧖れ振動が急激な増加を示す風速付近において風直角方 向の応答変位が増加する. 風直角方向応答変位の増加の割合は, 固有振動数比が小さなほど大きい.したがって, 風直角方向と据 れの固有振動数が接近した高層建筑物について振動依存風力を考 慮した風応答解析を行う場合, 振動依存風力の連成項も考慮する 必要がある.

\section{謝辞}

本論文に示した減衰定数 $0.5 \%$ 時の大振幅時までの弾性模型実験 は, (株) 風工学研究所の勝村章氏のご協力により実施したものであ る.記して謝意を表します。

\section{参考文献}

1) Vickery, B.J., Basu, R., Simplified Approaches to the evaluation of the across-wind response of chimneys, J. of Wind Eng. and Ind. Aerodyn, 14,153-166, 1983

2) Steckley, A., Motion-Induced Wind Forces on Chimneys and Tall Buildings, Ph.D thesis The university of Western Ontario, 1989

3) 大熊武司, 丸川比佐夫, 鶴見俊雄, 山本学, 高層建築物の空力不 安定振動の予測, 日本建築学会大会学術講演梗概集 (関東), $1127-1128,1993$ 年 9 月

4) 片桐純治, 大熊武司, 丸川比佐夫, 下村祥一, 辺長比 2 の高層建 築物に作用する振動依存風力特性に関する研究一風直角方向およ び㧖れ振動時振動依存風力特性一, 日本建築学会構造系論文集, 第 534 号, 25-32, 2000 年 8 月

5) 片桐純治, 丸川比佐夫, 大熊武司, 藤井邦雄, 高層建築物の風応 答における風直角方向と㨭れの固有振動数比の影響に関する研 究, 日本建築学会構造系論文集第 507 号, 21-27, 1998 年

6) 片桐純治, 勝村章, 丸川比佐夫, 藤井邦雄, 辺長比による高層 建築物の風直角方向および据れの風忘答性状の変化に関する研 究, 第 15 回風工学シンポジウム, 473-478, 1998 年

7) 丸川比佐夫, 片桐純治, 勝村章, 藤井邦雄, 多質点系弾性模型 の開発と高層建築物の風応答評価についての検討, 日本建築学会 構造系論文集, 第 484 号, 39-48，1996 年 6 月

8) 片桐純治, 大熊武司, 丸川比佐夫, 鶴見俊雄, 風直角㨭れ連成振 動時の振動依存風力特性一辺長比 2 の高層建築物に作用する振動 依存風力特性に関する研究一, 日本建築学会構造系論文集, 2000 年 5 月

9）大熊武司, 丸川比佐夫, 山本学, 矩形平面構造物の空力不安定 振動に関する実験的研究, 日本建築学会大会学術講演梗概集 (北 海道)，209-210，1995年 8 月

10) 勝村章, 片桐純治, 向秀元, 吉田昭仁, 丸川比佐夫, 高層建築 物の連成フラッターに関する研究, 日本建築学会大会学術講演梗 概集 (中国)，143-144，1999 年9月

11）片桐純治, 大熊武司, 丸川比佐夫, 振動依存風力を考慮した 風直角方向一㨝れ連成風応答解析に関する研究, 第 16 回風工学 シンポジウム論文報告集, 2000 年 12 月 